\title{
Modeling Water Quality Impacts of Growing Corn, Switchgrass, and Miscanthus on Marginal Soils
}

\author{
Mark A. Thomas ${ }^{1}$, Laurent M. Ahiablame ${ }^{1,2 *}$, Bernard A. Engel1, Indrajeet Chaubey ${ }^{1,3}$ \\ ${ }^{1}$ Department of Agricultural and Biological Engineering, Purdue University, West Lafayette, IN, USA \\ ${ }^{2}$ Department of Agricultural and Biosystems Engineering, South Dakota State University, Brookings, SD, USA \\ ${ }^{3}$ Department of Earth, Atmospheric, and Planetary Sciences, West Lafayette, IN, USA \\ Email: ${ }^{*}$ laurent.ahiablame@sdstate.edu
}

Received 29 August 2014; revised 25 September 2014; accepted 21 October 2014

Copyright @ 2014 by authors and Scientific Research Publishing Inc.

This work is licensed under the Creative Commons Attribution International License (CC BY).

http://creativecommons.org/licenses/by/4.0/

(c) (i) Open Access

\begin{abstract}
The goal of the study was to model water quality impacts of growing perennial grasses on marginal soils. The GLEAMS-NAPRA and RUSLE models were used to simulate long-term surface runoff, percolation, erosion, total phosphorus (TP), and nitrate $\left(\mathrm{NO}_{3}-\mathrm{N}\right)$ losses associated with the production of corn-based bioenergy systems (i.e. conventional tillage corn and corn grain plus stover removal), switchgrass and Miscanthus on three marginal quality soils and one good quality soil in Indiana. Simulations showed that switchgrass and Miscanthus had no effect on annual runoff, but decreased percolation by at least $\mathbf{1 7 \%}$. Results also suggested a potential for reduction in erosion for Miscanthus across the soil types examined when compared to corn-based bioenergy production. The production of switchgrass and Miscanthus did not have significant effects on the simulated TP and $\mathrm{NO}_{3}-\mathrm{N}$ losses in runoff compared to corn production systems. Nitrates leached from fertilized Miscanthus production were approximately $90 \%$ lower than $\mathrm{NO}_{3}-\mathrm{N}$ leached from the production of fertilized switchgrass and corn systems. Additional studies are needed to better understand the hydrology, erosion and nutrient responses of Miscanthus and switchgrass production to meet bioenergy demands.
\end{abstract}

\section{Keywords}

Water Quality Modeling, Perennial Grass, Runoff, Biofuels, Marginal Lands, GLEAMS-NAPRA

\section{Introduction}

Over the past few years, the interest to intensify renewable energy production resulted in increased attention for

"Corresponding author.

How to cite this paper: Thomas, M.A., Ahiablame, L.M., Engel, B.A. and Chaubey, I. (2014) Modeling Water Quality Impacts of Growing Corn, Switchgrass, and Miscanthus on Marginal Soils. Journal of Water Resource and Protection, 6, $1352-1368$. 
growing biofuel feedstock on lands not used for food production. The EISA also mandated the Advanced Renewable Fuels Standard (RFS2) to establish guidelines that would require fuel producers to use 79 billion liters of biofuel by 2022, with set benchmarks for low-input production systems for cellulosic and other advanced biofuels [1]. The reluctance of producers and market uncertainties of non-food feedstock such as perennial grasses prompted the government to provide additional support to US bioenergy production efforts through the Food, Conservation and Energy Act of 2008, also known as the 2008 US Farm Bill [2]. Through the 2008 Farm Bill, the Biomass Crop Assistance Program (BCAP) was created to support market assurance by providing incentives to interested producers for the establishment and cultivation of biomass crops for heat, power, bio-based products, and biofuels [3] [4]. With these incentives, not only increased quantity of corn and soybean would be shifted towards biofuels, but also considerable conversion of traditionally intensively managed lands for corn and soybean production can be expected in the Midwest, including Indiana, to produce energy grasses.

There is increased interest for biofuel production on marginal lands (i.e. low quality soils), as this avoids competition with food crops [5]-[8]. Marginal lands mean different things in different locations, contexts, and purposes, such that it becomes difficult to precisely estimate the available amount of marginal lands suitable for bioenergy crops [5]. Depending on time and location, marginal land may be characterized as "idle, under-utilized, barren, inaccessible, degraded, excess or abandoned lands, lands occupied by politically and economically marginalized populations, or land with characteristics that make a particular use unsustainable or inappropriate” [5]. In farming, marginal land refers to a land area that would likely yield poor return for food production. Research showed that biofuel feedstocks are capable of growing on soils with naturally poor conditions (for agriculture) due to their high efficiency for water and nutrient use [9]-[13].

The most popular crops for biofuel energy production in the United Sates include corn, soybeans, and perennial grasses such as switchgrass (Panicumvirgatum), big bluestem (Andropogongerardii), Indiangrass (Sorghastrumnutans) and Miscanthus $\times$ giganteus [14] [15]. In this study, the perennial grasses considered consist of switchgrass and Miscanthus due to their potential adaption to Indiana's climatic conditions. Switchgrass is a tall prairie grass that is native to the United States. Adaptable to a wide range of climates, resistant to disease and pests, switchgrass has been shown to be an attractive biomass candidate [16] [17], with high yielding lowland varieties that can produce up to 20 dry metric tons per hectare [18]. Miscanthus $\times$ giganteus is a sterile perennial grass, relatively new to the United States and has high biomass yield potential [19]. The cold-tolerant Miscanthus hybrid is capable of retaining high $\mathrm{C}_{4}$ photosynthetic activities at temperatures as low as $8^{\circ} \mathrm{C}$, with increased productivity potential under increasing precipitation, making it suited to the rain-fed Midwest regions [19].

As the demand for corn-based ethanol increases, so does the stress on farm acreage, originally used for conventional crop production, with potential environmental impacts that would not compensate for the benefits [20]. In a modeling study conducted in Indiana, Thomas et al. [21] reported that shifting corn rotation to continuous corn cultivation (as would be the case for meeting biofuel demand) would influence percolation, erosion, runoff, and subsequent nutrients and pesticides losses from agricultural fields. Schilling and others [22], after evaluating potential impacts of future land use and land cover change on annual and seasonal water balance within the Raccoon River watershed (Iowa), concluded that increase in corn production would decrease annual ET but increase runoff as well as losses in nitrate $\left(\mathrm{NO}_{3}-\mathrm{N}\right)$, phosphorus $(\mathrm{P})$ and sediments compared to a warm season grass (i.e. switchgrass) and a typical cool season grass grown for ethanol biofuel. Field and watershed scale analyses demonstrated that corn cultivation with stover removal may also lead to increased erosion and increased runoff losses [23] [24]. Even though harvesting corn stover for biofuel production could reduce agricultural pollutant losses if the appropriate amount is removed [25]-[27], the production of switchgrass and Miscanthus have been shown to have reduced pollutant loading to receiving water bodies [28]-[30].

In light of the above highlights of environmental benefits of bioenergy crops, it is necessary to fully investigate environmental implications associated with growing biofuel crops on marginal lands. Currently, there are no known studies that examined water quality implications of corn, switchgrass, and Miscanthus production on marginal agricultural lands in Indiana. Moreover, water quality impacts of stover removal on agronomically marginal soils were not studied. The objectives of this study were to 1) quantify through long-term simulations the runoff, percolation, erosion, and nutrient losses attributable to switchgrass and Miscanthus on three soils of marginal quality and one non-marginal soil in Indiana; and 2) compare these water quality metrics of perennial grass production to the production of conventional tillage bioenergy corn and conventional tillage bioenergy corn plus stover removal. 


\section{Materials and Methods}

A field-scale modeling framework, which utilized the Groundwater Loading Effects of Agricultural Management Systems-National Agricultural Pesticide Risk Analysis (GLEAMS-NAPRA) model and the Revised Universal Soil Loss Equation (RUSLE 2.0) [23] [31], was used to simulate the production of corn and two perennial grasses on three marginal quality soils in Decatur County and one non-marginal soil in Allen County in Indiana for a continuous 32-year period. The scenarios simulated consist of conventional tillage corn, no-till corn, conventional tillage corn with 70\% stover removal, switchgrass, and Miscanthus. All corn systems simulated in this study are for biofuel production. Conventional tillage corn with stover retained was assumed to be the baseline condition for all simulation scenarios.

\subsection{Study Sites and Selection of Marginal Quality Soils}

This study used Blount silt loam, a non-marginal soil, as base soil for corn (conventional tillage with stover retained, no-till with stover retained, and conventional tillage corn with $70 \%$ stover removal), switchgrass and Miscanthus simulations. These cropping management systems were also evaluated in this study on three marginal soils: Miami clay loam, Cincinnati silt loam, and Clermont silt loam in Decatur County in southern Indiana (Figure 1). Southern Indiana was selected because previous researchers identified a need to supply biomass to facilities in southern Indiana [32]. The NRCS' Land Capability Classification (LCC) was used to determine the marginal quality soils with the Soil Survey Geographic (SSURGO) database (Table 1). As defined by SSURGO metadata, LCC is a system of grouping soils primarily on the basis of their capability to produce common cultivated crops and pasture plants without any deterioration over a long period of time [33]. Each SSURGO soil map unit is assigned a capability class ranging from 1 to 8, and a sub-class assigned by letters to describe limitations or hazards for agricultural purposes. SSURGO LCC 3's (wetness) and 4's (erodibility) were considered suitable marginal lands for large-scale perennial grass production.

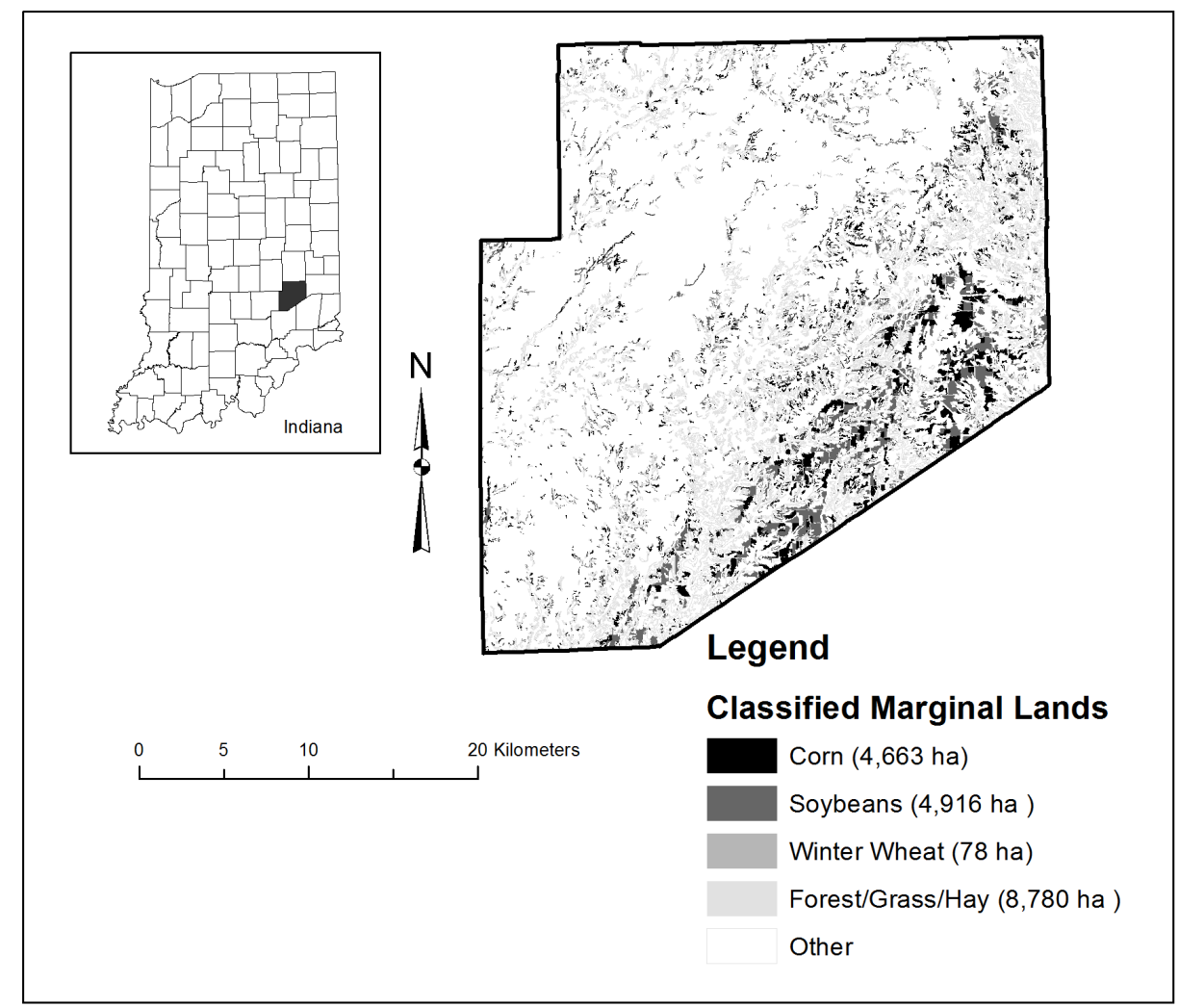

Figure 1. Distribution of land uses in Decatur County where marginal quality soils were selected with NASS 2010 and NRCS Land Capability Classification (LCC) used for the simulation of dedicated energy crops. 
Table 1. General soil physical characteristics obtained from Soil Survey Geographic (SSURGO) database for three marginal quality soils (NRCS, Land Capability Class) by area in Decatur County, and one non-marginal soil in Allen County, Indiana.

\begin{tabular}{ccccccccccc}
\hline Soil Name, Map Symbol & $\mathrm{Kw}^{\text {[a] }} \begin{array}{c}\text { Slope } \\
(\%)\end{array}$ & $\begin{array}{c}\text { Depth } \\
(\mathrm{cm})\end{array}$ & $\begin{array}{c}\text { Porosity } \\
\left(\mathrm{cm}^{3} / \mathrm{cm}^{3}\right)\end{array}$ & $\begin{array}{c}\theta 33 \mathrm{kPa}[\mathrm{b}] \\
(\mathrm{cm} / \mathrm{cm})\end{array}$ & $\begin{array}{c}\theta 1500 \mathrm{kPa} \\
(\mathrm{cm} / \mathrm{cm})\end{array}$ & $\begin{array}{c}\text { SatK } \\
(\mathrm{mm} / \mathrm{hr})\end{array}$ & $\begin{array}{c}\text { Sand } \\
(\%)\end{array}$ & $\begin{array}{c}\text { Silt } \\
(\%)\end{array}$ \\
$(\%)$
\end{tabular}

$\left.{ }^{[a}\right]$ Kw: Soil erodibility factor. ${ }^{[b]} \theta 33 \mathrm{kPa}$, is field capacity. ${ }^{\left[{ }^{[c]}\right.} \theta 1500 \mathrm{kPa}$ is the wilting point at suction pressure $1500 \mathrm{kPa} .{ }^{\text {[d] }}$ Porosity, field capacity, and wilting point values for soil layers obtained GLEAMS documentation.

In this study, initial evidence from a GIS analysis suggested that land classes of 5 to 8 would not be suitable for perennial grass production for bioenergy due to restrictions such as rocks or high slopes (25\% or greater), which would make in-field operations difficult or impractical. One marginal soil due to wetness (Clermont silt loam, land capability class-3w) and two marginal soils due to high erodibility (Miami clay loam and Cincinnati silt loam, land capability class-4e) were selected based on their abundance in Decatur County, Indiana. At the time of this study, $62 \%$ of these soils was cropped with corn (so corn was selected as the base crop), using the 2010 Cropland Data Layer [34]. It is worth noting that land capability class-3w's can be prime farmlands if properly drained (perhaps because they are for the most part already drained in this county).

\subsection{GLEAMS Model and Input Data Description}

The GLEAMS model is a computer program developed to simulate edge-of-field and bottom-of-root-zone loadings of water, sediment, pesticides, and plant nutrients [35]. The major components of the model include hydrology, erosion, nutrient and pesticides. These components can simulate the effects of land management practices on a daily basis utilizing climate, soil, and management data inputs [35]. Erosion prediction in GLEAMS is estimated using the Universal Soil Loss Equation (USLE). The crop management factor (C-fact) drives GLEAMS erosion computation associated with land management and is not dynamically computed and as such requires user-defined input values. C-factor inputs for management operations (Table 2) are critical for accurate erosion prediction by the model. The RUSLE 2.0 model [36] was used to generate daily C-factor values for corn and perennial management systems, of which the mean annual C-factor values were reported in Table 2. To generate C-factor values for Miscanthus, the switchgrass template was modified to reflect increased plant biomass production and management to obtain estimates for C-factor values required by GLEAMS. The choice of the GLEAMS model for this study was driven by the model capability to simulate edge-of-field hydrology, erosion, nutrients and pesticides and to represent biomass production [37].

Continuous daily precipitation and temperature were required for climatic inputs in the GLEAMS model [37] (Knisel and Davis 2000). Climatic data were generated for Decatur County, Indiana, using a weather generator known as CLIGEN, version 4.3 [38] [39]. CLIGEN is a stochastic weather generator that statistically derives daily precipitation, temperature, dewpoint temperature, wind, and solar radiation with historic measurements for a given geographic point. The nearest climate stations $\left(39^{\circ} 21^{\prime} 00^{\prime \prime} \mathrm{N}, 85^{\circ} 28^{\prime} 48^{\prime \prime} \mathrm{W}\right)$ in Greensburg, southeastern Indiana, provided the required input parameters for the weather generator program. CLIGEN is packaged with the Water Erosion Prediction Project (WEPP) model [38] [39]. CLIGEN has a database, with a graphical user-friendly feature, for more than 2600 weather stations in the United States. It is often used also by other hydrologic/water quality models such as the Soil Water Assessment Tool (SWAT) [40] [41].

Porosity, field capacity, and wilting point are sensitive parameters in the GLEAMS model [37]. Soil physical properties required to run the model were obtained from the SSURGO database. The available water content (AWC) data in SSURGO were used to compute the wilting point. However, in a few cases, very low AWC val- 
Table 2. Net annual residue cover management factors (C-factor) for bioenergy crops generated with the Revised Universal Soil Loss Equation, Version 2 (RUSLE 2) model and used as user-defined inputs in GLEAMS.

\begin{tabular}{lcccc}
\hline Biofeedstock & $\begin{array}{c}\text { Miami clay } \\
\text { loam, MoC3 }\end{array}$ & $\begin{array}{c}\text { Cincinnati silt } \\
\text { loam, CkC3 }\end{array}$ & $\begin{array}{c}\text { Clermont silt } \\
\text { loam, Cm }\end{array}$ & $\begin{array}{c}\text { Blount silt } \\
\text { loam, BmB2 }\end{array}$ \\
\hline Corn & & & & 0.01 \\
$\quad$-No-till & 0.02 & 0.02 & 0.10 & 0.10 \\
$\quad$-Conventional tillage & 0.12 & 0.15 & 0.10 & 0.10 \\
$\quad$-Stover removal & 0.12 & 0.15 & & 0.011 \\
Switchgrass & & & & 0.016 \\
$\quad$ Post-establishment & 0.015 & 0.014 & & 0.001 \\
$\quad$ Miscanthus & & & 0.001 & \\
$\quad$ Post-establishment & 0.001 & &
\end{tabular}

ues in SSURGO were not justified by the associated textural class descriptions, especially at soil depths of $5 \mathrm{~cm}$ or less on the studied soils. This could impact model estimates for hydrology and water quality. In the absence of justification for low AWC in the SSURGO documentation, GLEAMS description of porosity, wilting point, and field capacity values associated with soil type were used for soil layers deemed invalid.

Prior research and experience of the authors, as well as that of other researchers, has shown that calibration of the GLEAMS model is not required, especially when comparing the relative impacts of scenarios as was done in this paper [42]-[45]. For example, Jetten et al. [44] evaluated six models, including GLEAMS, on seven sites with 73 site-years of erosion data. They concluded that relative model results were more reliable than absolute results and application of the models without calibration is appropriate. Knisel et al. [45] conducted a sensitivity analysis on the hydrology portion of GLEAMS as part of a GLEAMS water balance validation. They found that fine tuning of the four most sensitive parameters (curve number, rooting depth, porosity and field capacity) slightly improved simulated runoff, percolation and evapotranspiration. They concluded that the results of the GLEAMS validation support prior statements that calibration of the model is not required.

The GLEAMS model has been shown to perform well for Indiana conditions in prior work [42] [46] [47]. The GLEAMS model has previously been calibrated and validated for monthly runoff, sediment, $\mathrm{NO}_{3}-\mathrm{N}$, and $\mathrm{P}$ under corn-soybean cropping systems for two small watersheds in Allen County (northeast Indiana) [42], and for pesticide (atrazine) losses on Clermont Silt Loam soil in southern Indiana [46]. The simulation scenarios discussed in this study were run with the calibrated parameters for Allen County watersheds and the Clermont Silt Loam [42] [46].

\subsection{Representation of Perennial Grasses in GLEAMS}

The GLEAMS model uses a simple crop growth model driven by leaf area index (LAI) values for fractions of the growing season (Figure 2). Leaf area index is defined as the ratio of the leaf surface area to the soil area the leaf covers [48]. It can be used to describe the canopy structure as well as biomass of a plant [48].The internal database of the model provides values of LAI for 78 different crops. A user-defined option allows for the simulation of crops that are not included in the model database. Switchgrass and Miscanthus characteristics required to run the model are provided in Table 3. The model allows for pairs of LAI data (NOLAI) with corresponding fraction of the growing season (USRFRC), and user defined LAI (USRLAI) for non-stressed crop [37]. The model dynamically adjusts for actual LAI using crop stress factors. For the model to best simulate crop growth, LAI and crop height (CROPHT) are required for the periods where LAI was provided [37]. Leaf area index data are not sensitive to the water balance computation, in GLEAMS, but are sensitive to soluble $\mathrm{NO}_{3}-\mathrm{N}$ and $\mathrm{P}$ uptakes [37]. Leaf area index values for established switchgrass and Miscanthus were obtained from data presented in Heaton et al. [9].

Engel et al. [49] proposed a split simulation approach to represent perennial establishment and full maturity in the SWAT model by modifying an algorithm for simulation of forest trees to represent perennial grasses. The representation of crops with an establishment year and harvesting in subsequent years can be readily performed with the GLEAMS model (Figure 3). However, the simulated data for establishment of the perennial grasses 


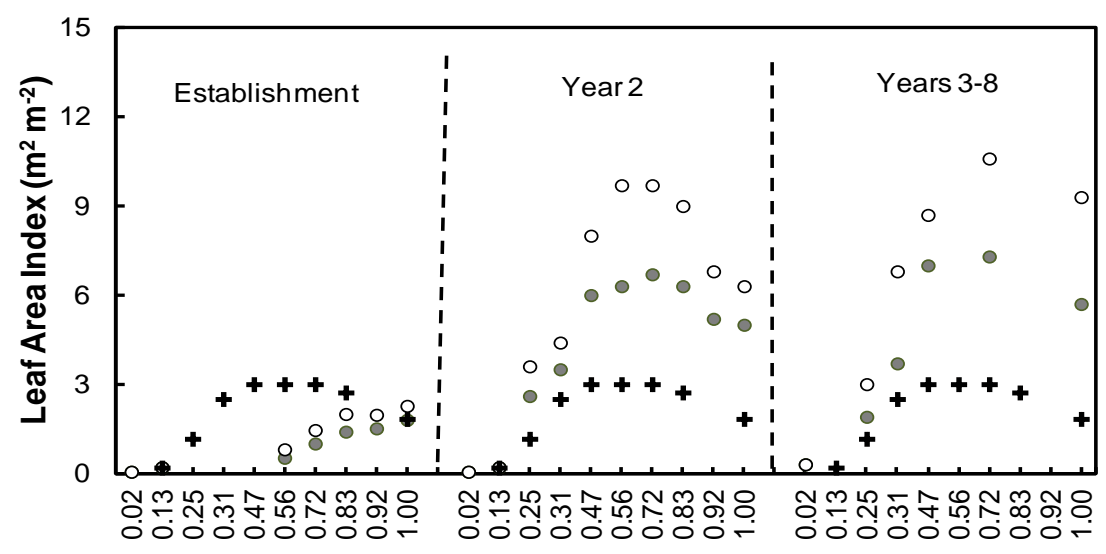

\section{Fraction of the Growing Season}

- Switchgrass o Miscanthus + Corn

Figure 2. Leaf area index (LAI) as fraction of the growing season for switchgrass, Miscanthus $\times$ giganteus, and corn used to simulate perennial growth with the GLEAMS model. Post-establishment LAI data were adapted from Heaton and others (2008) using data from canopies in east-central Illinois $\left(40.08^{\circ} \mathrm{N}, 88.23^{\circ} \mathrm{W}\right)$. Establishment LAI data for M. giganteus were obtained from 2010 plot data from the ThrockmortonPurdue Agricultural Center (TPAC), west-central Indiana $\left(40.30^{\circ} \mathrm{N} ; 86.90^{\circ} \mathrm{W}\right)$. Corn LAI data were obtained from GLEAMS-NAPRA internal database.

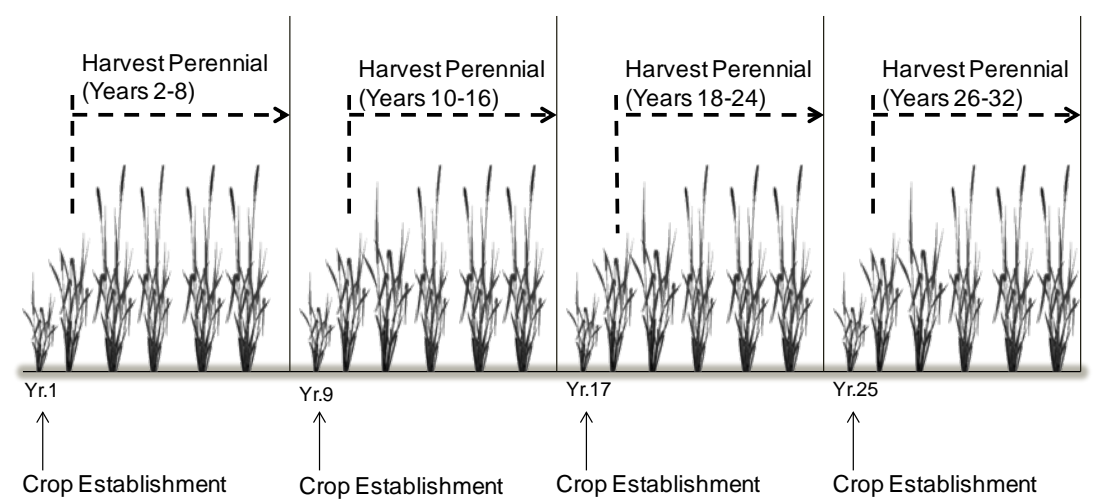

Figure 3. Schematic of switchgrass and Miscanthus $\times$ giganteus representation in the GLEAMS model for crop establishment to full maturity. Establishment of the perennial grasses was not modeled in this study.

Table 3. Crop characteristics required by the GLEAMS model.

\begin{tabular}{|c|c|c|c|}
\hline Parameter & Switchgrass ${ }^{[a]}$ & Miscanthus $\times$ giganteus & References \\
\hline Potential yield (PY, in kg/ha) & $10.4 \mathrm{Mg} / \mathrm{ha}$ & $29.6 \mathrm{Mg} / \mathrm{ha}$ & Heaton and others (2008) \\
\hline Carbon-nitrogen ratio at harvest (CNR) & 80 & 80 & GLEAMS database $^{[\mathrm{b}]}$ \\
\hline Ratio of nitrogen to phosphorus (RNP) & 6.7 & 6.7 & GLEAMS database $^{[\mathrm{b}]}$ \\
\hline Coefficient (C1) of nitrogen content of the crop & 1.25 & 1.25 & GLEAMS database $^{[b]}$ \\
\hline Exponent (C2) of nitrogen content of the crop & -0.278 & -0.278 & GLEAMS database $^{[\mathrm{b}]}$ \\
\hline PERNNL $^{[\mathrm{c}]}$ & 1 & 1 & GLEAMS Manual \\
\hline Total dry matter to yield (DMY) & 1.35 & 1.35 & GLEAMS database $^{[\mathrm{b}]}$ \\
\hline Effective Rooting depth $^{[\mathrm{d}]}$ & $91.4 \mathrm{~cm}$ & $91.4 \mathrm{~cm}$ & Thomas and others (2011) \\
\hline Maximum crop height (CRPHTX) & $250 \mathrm{~cm}$ & $366 \mathrm{~cm}$ & Purdue Water Quality Field Station (ACRE) \\
\hline
\end{tabular}

${ }^{[a]}$ Cave-in-Rock, upland switchgrass. ${ }^{[b]}$ Warm-season grasses $\left(\mathrm{C}_{4}-\mathrm{C}\right)$ in the model's internal database. ${ }^{\left[{ }^{[c]}\right.}$ Perennial crop: used by the model to indicate that the root growth does not begin at zero depth after each cutting. 
were not discussed in this study. The model's internal database provides crop characteristics for perennials such as forest, warm- $\left(\mathrm{C}_{4}\right)$ and cool- $\left(\mathrm{C}_{3}\right)$ season grasses.

\subsection{Corn, Switchgrass, and Miscanthus Management}

Conventional tillage (fall chisel plowing and spring disking) with stover retained, no-till with stover retained, and conventional tillage corn with $70 \%$ stover removal practices in a continuous production system were considered for corn production scenarios. However, stover removal was considered only with no-till management practice in conformity with the guidelines of a Department of Energy Study [15]. Thomas and others (2011) modified the GLEAMS algorithm to represent the above surface residue removal following grain harvest. Details of model inputs such as planting date, harvesting date, fertilizer rates, adjustments and timing are provided in Thomas et al. [23] and Thomas [31]. Fertilizer application rates with compensation for nutrient replacement due to stover removal at $70 \%$ varied across the four studied soils (Table 4).

Switchgrass is a warm-season crop and as such would require temperatures greater than $25^{\circ} \mathrm{C}$ for optimal germination and growth [50]. In the central Great Plains and Midwest, switchgrass can be planted within $+/-3$ weeks of the corn planting date [17]. In Indiana, switchgrass planting date is expected to coincide with corn; therefore, the median planting date reported by Thomas et al. [43] was used in this study.

For model simulations, conventional tillage corn with stover retained was assumed as the baseline crop and as such two tillage operations (spring-disk followed by seed-drill) were assumed during establishment years with single yearly harvest for years 2 to 8 . Spring-drill operation was performed at a depth of $1.27 \mathrm{~cm}$, which is the maximum recommended for switchgrass. Spring emergence date of established switchgrass stands was assumed to be April $14^{\text {th }}$, the expected date for the last spring freeze in southern Indiana. A harvest date of October $18^{\text {th }}$, associated with Indiana plot studies, was used for switchgrass management (Jeff Volenec, personal communication). In the model representation, it was assumed that harvest was $80 \%$ (8320 kg/ha) for year 2, 90\% for year 3 (9360 kg/ha), and maximum yield (100\%) for years 4 to 8 (Keith Johnson, personal communication). Perennials such as switchgrass require some level of management to optimize productivity and maintain quality stands for multiple years of harvest [17]. Previous studies reported that switchgrass could be productive for more than 10 years [51] [52].

General agronomic guidelines for the Midwest region do not recommend nitrogen application during the establishment year to minimize competition with weeds, which could lead to stand or establishment failure [53]. On established switchgrass stands, a single application of nitrogen fertilizer in the form of urea was programed for May $6^{\text {th }}$. A nitrogen fertilizer rate of $112 \mathrm{~kg} /$ ha was applied to maintain biomass production levels, assuming yearly harvest of upland varieties such as Shawnee or Cave-in-Rock. To maintain maximum yields and to avoid soil mining of $\mathrm{P}$, a single annual application rate of $34 \mathrm{P}_{2} \mathrm{O}_{5} \mathrm{~kg} / \mathrm{ha}$ was assumed for model simulations [54].

Miscanthus is propagated by rhizome division, and no-tilling rhizomes in crop residue would likely be the adopted practice when production reaches its full stage. In United States, researchers reported that Miscanthus yields vary with location, with a range of 27 to 44 t/ha [19]. In Indiana, Miscanthus would likely be established approximately the same date as corn (May 6) with no harvest during the establishment year. A harvest date of October $18^{\text {th }}$, associated with Indiana plot studies, was used for Miscanthus management (Jeff Volenec, personal communication). Miscanthus is cold tolerant and as such it was reasonable to assume that spring emergence of established Miscanthus stands was April 1st, 2 weeks earlier than the expected date of last spring freeze in southern Indiana. The first harvest was projected in year 2 at $90 \%$ of maximum yield with maximum yields achieved from years 3 to 8 (29.6 t/ha). There is currently limited knowledge on the long-term Miscanthus growth, and re-establishment of Miscanthus stands required to optimize bioenergy production with yearly perennial harvest. Consequently, stand re-establishment was set to occur after the year 8 , similar to the production of switchgrass practice assumed in this study. To maintain maximum yields as well as avoiding soil mining of $P$, a yearly application rate of $34 \mathrm{P}_{2} \mathrm{O}_{5} \mathrm{~kg} /$ ha was assumed for model simulations [54]. Fertilizer application rates of $112 \mathrm{~N} \mathrm{~kg} / \mathrm{ha}$ (broadcasted as urea) were applied in production years (Patrick Murphy, personal communication).

\subsection{Statistical Analysis}

Tukey and Bonferroni pairwise comparison tests were used to evaluate differences among mean annual surface runoff, percolation, and losses in erosion, $\mathrm{TP}$, and $\mathrm{NO}_{3}-\mathrm{N}$ associated with biofeedstock management scenarios within each soil unit. Prior to hypothesis testing, exploratory data analyses (EDA) were performed to check for 
independence of variables, normality, and homogeneity of variances. When assumptions were violated, the datasets were log-transformed prior to the analyses (Table 5; [55]). All the analyses were performed with the $\mathrm{SAS}^{\mathrm{STAT}}{ }^{\circledR}$ software, version 9.2 [56] at a significance level of 0.05 .

\section{Result and Discussion}

During the analysis of runoff and percolation, all corn management options (conventional tillage, no-till and conventional tillage corn plus $70 \%$ stover removal) were evaluated as one cropping system, herein referred to as corn production, and compared to perennial grasses. Initial statistical analyses revealed no significant differences in the long-term model estimates of surface runoff and percolation losses for the three corn production options for the four studied soils $(\mathrm{p}>0.05)$.

\subsection{Surface Runoff Comparisons for Perennial Grasses and Corn}

The simulation scenarios resulted in 1 to $4 \mathrm{~mm}$ decrease in annual surface runoff with Miscanthus and switchgrass production compared to corn-based bioenergy production (Figure 4). These results suggested that the production of perennial grasses have no meaningful effects on runoff, which is consistent with the Nyakatawa et al. [57] (2006) plot study comparing runoff from corn and switchgrass. However, other studies reported significant runoff reduction from perennial C4 grasses compared to corn production [22] [58]-[60]. The differences in surface runoff between corn- and grass-based bioenergy systems in this study were not statistically significant ( $p>0.05$ ). The similarities in runoff production between corn and perennial grasses in this study (Miscanthus and switchgrass) could be driven by factors influencing soil characteristics after intensive corn and soybean production on these soils. These factors include type and amount of cover, soil structure, and soil moisture content at the beginning of the precipitation season [61] [62]. Under these conditions, the soil physical characteris tics will likely have greater influence on long-term annual runoff estimates than crop production systems would

Table 4. Corn-on-corn fertilizer recommendation rates [23] associated with soil potential yields for the studied Indiana soils.

\begin{tabular}{|c|c|c|c|c|}
\hline Soil (potential grain yield) & $\begin{array}{l}\text { Miami clay loam } \\
(7.6 \mathrm{Mg} / \mathrm{ha})\end{array}$ & $\begin{array}{l}\text { Cincinnati silt loam } \\
(6.3 \mathrm{Mg} / \mathrm{ha})\end{array}$ & $\begin{array}{l}\text { Clermont silt loam } \\
\text { (10.5 Mg/ha) }\end{array}$ & $\begin{array}{l}\text { Blount silt loam } \\
\text { (8.4 Mg/ha) }\end{array}$ \\
\hline Estimated residue after harvest $(\mathrm{t} / \mathrm{ha})^{[\mathrm{a}]}$ & 6.0 & 5.0 & 8.4 & 6.7 \\
\hline \multicolumn{5}{|l|}{ Commercial fertilizer rate } \\
\hline \multicolumn{5}{|l|}{ No residue removal application rates } \\
\hline Nitrogen (kg/ha) & 151 & 121 & 221 & 173 \\
\hline $\mathrm{P}_{2} \mathrm{O}_{5}(\mathrm{~kg} / \mathrm{ha})$ & 37 & 31 & 52 & 41 \\
\hline \multicolumn{5}{|c|}{ Application rates at $70 \%$ stover removal $^{[\mathrm{b}]}$} \\
\hline Nitrogen (kg/ha) & 185 & 149 & 268 & 210 \\
\hline $\mathrm{P}_{2} \mathrm{O}_{5}(\mathrm{~kg} / \mathrm{ha})$ & 49 & 41 & 69 & 54 \\
\hline
\end{tabular}

${ }^{[a]}$ See Thomas et al. [23]. ${ }^{[b]}$ Stover harvested at 4.2 t/ha, 3.5 t/ha, 5.9 t/ha and 4.7 t/ha for Miami clay loam, Cincinnati silt loam, Clermont and Blount silt loam, respectively.

Table 5. Log-transformed datasets for statistical analysis for Switchgrass and Miscanthusfor the three studied soils (N: No log-transformed; Y: Log-transformed).

\begin{tabular}{lcccccc}
\hline Soils & Surface runoff & Percolation & Erosion & Total P & Nitrates w/Runoff & Nitrates leached \\
\hline Blount-tillage & $\mathrm{N}$ & $\mathrm{N}$ & $\mathrm{N}$ & $\mathrm{N}$ & $\mathrm{Y}$ & $\mathrm{Y}$ \\
No-till & $\mathrm{N}$ & $\mathrm{N}$ & $\mathrm{Y}$ & $\mathrm{N}$ & $\mathrm{Y}$ & $\mathrm{Y}$ \\
Hoytville-tillage & $\mathrm{N}$ & $\mathrm{N}$ & $\mathrm{Y}$ & $\mathrm{Y}$ & $\mathrm{Y}$ & $\mathrm{Y}$ \\
No-till & $\mathrm{N}$ & $\mathrm{N}$ & $\mathrm{Y}$ & $\mathrm{N}$ & $\mathrm{Y}$ & $\mathrm{Y}$ \\
Oshtemo-tillage & $\mathrm{N}$ & $\mathrm{N}$ & $\mathrm{Y}$ & $\mathrm{Y}$ & $\mathrm{Y}$ & $\mathrm{Y}$ \\
No-till & $\mathrm{N}$ & $\mathrm{N}$ & $\mathrm{Y}$ & $\mathrm{N}$ & $\mathrm{Y}$ & $\mathrm{N}$ \\
\hline
\end{tabular}




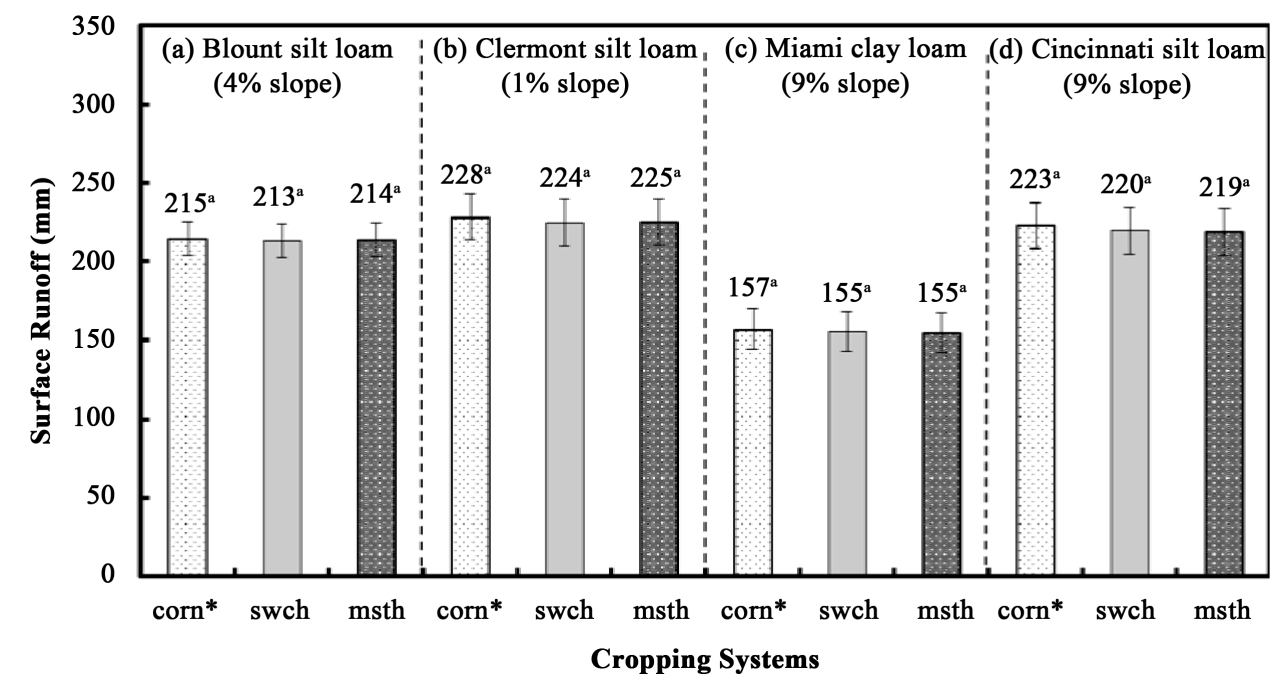

Figure 4. Estimates in mean surface runoff for continuous corn, switchgrass (swch) and Miscanthus $\times$ giganteus (msth), obtained from long-term GLEAMS-NAPRA model simulations on one prime agricultural soil (a) (Blount silt loam) and three marginal soils (b) Clermont silt loam; (c) Miami clay loam; (d) (Cincinnati silt loam) in southeastern Indiana. Within each soil, means with the same letter are not significantly different (Tukey test, $\mathrm{p}>0.05$ ).

during similar growing periods. For example, the highest runoff estimates were obtained from the Clermont soil, which is relatively flat, poorly drained, and agronomically marginal with high water content compared to the other two marginal soils, which are moderately well to well drained soils. Even though research efforts exist in the scientific literature regarding the hydrologic benefits of perennial grass production [22] [58] [59], the specific impacts of Miscanthus and switchgrass production on long-term surface runoff is still not fully examined for various soils (including marginal quality soil).

Surface runoff is partly driven by ET; thus accurate estimation of ET is critical for water balance computations. In this study, annual estimates of ET on the studied marginal quality soils ranged from 721 to $743 \mathrm{~mm}$ for Miscanthus, 711 to $744 \mathrm{~mm}$ for switchgrass and 679 to $718 \mathrm{~mm}$ for corn. The model's ET estimates were within range of a land use land cover study that included the study area of this project, which estimated $720 \mathrm{~mm}, 710$ $\mathrm{mm}$, and $670 \mathrm{~mm}$ for Miscanthus, switchgrass and corn, respectively [13]. Currently, there are knowledge gaps on switchgrass and Miscanthus production in Indiana that need to be explored in order to improve modeling accuracy. Further studies are needed to understand the long-term runoff expected from the production of dedicated perennial grasses.

\subsection{Percolation Comparisons for Perennial Grasses and Corn}

Percolation is the downward movement of water through the soil profile. Model results showed decrease in percolation below the root zone by 11 to $40 \mathrm{~mm}$ for Miscanthus and 11 to $31 \mathrm{~mm}$ for switchgrass compared with corn-based bioenergy production (Figure 5). Mean annual percolation estimates associated with corn-based bioenergy on the studied soils ranged from 77 to $187 \mathrm{~mm}$, with highest estimates on Miami clay loam soil (9\% slope). McIsaac et al. [58] measured soil moisture at a depth of $94 \mathrm{~cm}$ and reported declines in moisture level with Miscanthus and switchgrass compared to corn-soybean rotation. Their study reported a 4-year soil moisture average difference of $45 \mathrm{~mm}$ between switchgrass and Miscanthus at the end of the growing season, with little difference during dry years. This would suggest that percolation estimates from fully mature Miscanthus would be lower than that associated with corn and switchgrass, a trend that is consistent with this study. Although the researchers credited high LAI and biomass for lower Miscanthus soil moisture, the establishment period was not represented in the analysis. Corn is an annual crop and as such has greater maximum LAI values than Miscanthus and switchgrass during establishment periods (Figure 2). Consequently, including the establishment year in the analysis would increase soil moisture averages because Miscanthus is slow to establish [6]. In addition, Finch and Riche [63] noted that late in the growing period, Miscanthus intercepts $20 \%$ of rainfall, influencing 


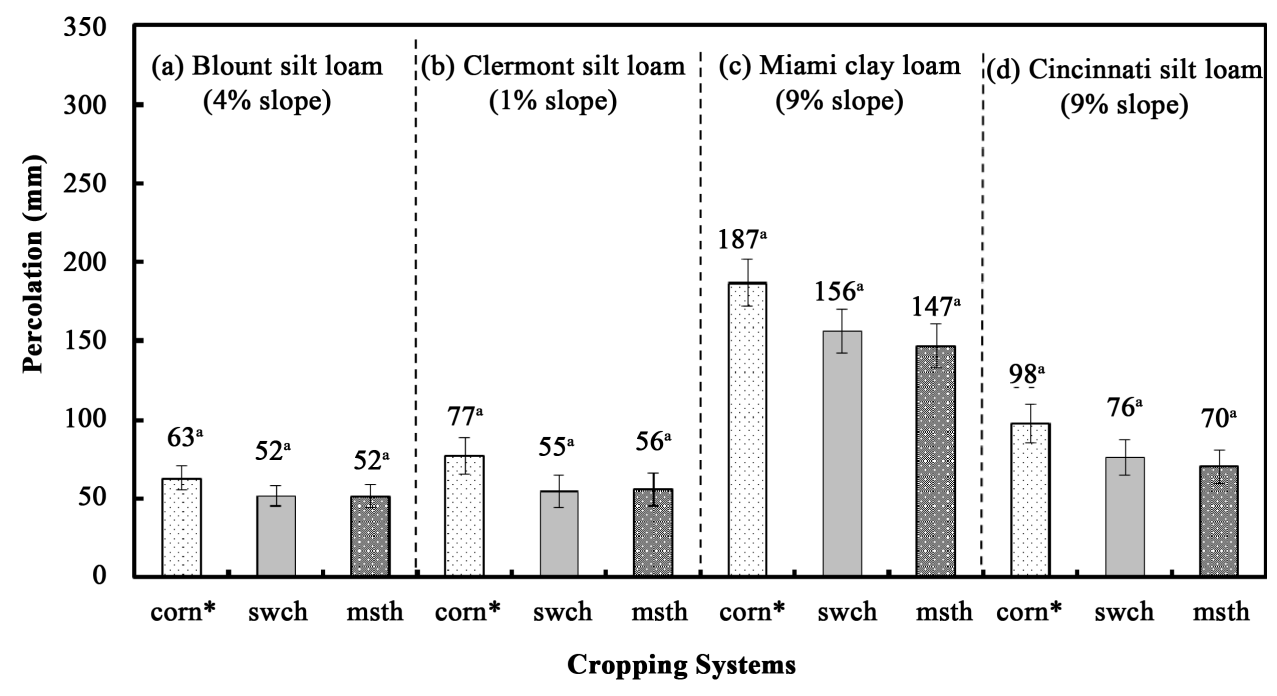

Figure 5. Estimates in mean percolation for continuous corn, switchgrass and Miscanthus $\times$ giganteus (msth), obtained from long-term GLEAMS-NAPRA model simulations on one prime agricultural soil (a) (Blount silt loam) and three marginal soils; (b) Clermont silt loam; (c) Miami clay loam; (d) (Cincinnati silt loam) in southeastern Indiana. Within each soil, means with the same letter are not significantly different (Tukey test, $\mathrm{p}>0.05$ ).

evaporation from stems and leaves (canopy evaporation). The researchers argued that the quantity intercepted by Miscanthus late in the growing season is more typical of a forest than annual agricultural crops, which could explain measured greater depletion of soil moisture.

\subsection{Erosion Losses from Perennial Grasses and Corn Systems}

Thirty to $60 \%$ decrease in erosion occurred with Miscanthus production in comparison with continuous corn with tillage and conventional tillage corn plus 70\% stover removal (Figure 6). No-till corn without stover harvesting had lower erosion losses than switchgrass production, with differences ranging from 0.1 to $2.4 \mathrm{t} / \mathrm{ha}$ (Figure 6). Large amounts of plant residue associated with no-till corn and low residue with harvested switchgrass could influence the amount of soil cover that could mitigate erosion. However, Miscanthus, which was no-tilled when established, produced lower erosion than no-till corn by at least $30 \%$ on the studied soils (Figure 6).

Miscanthus and switchgrass production on highly erodible lands such as Miami clay loam (9\% slope) and Cincinnati silt loam ( $9 \%$ slope) is believed to be suitable in mitigating erosion risks associated with production practices. Successful production of switchgrass and Miscanthus could reduce erosion below the soil loss tolerance ( $\mathrm{T}$ factor) of $6.72 \mathrm{t} / \mathrm{ha}$ on Miami clay loam. Cincinnati silt loam has higher soil erodibility factor $\left(\mathrm{K}_{\mathrm{w}}=0.49\right)$ and lower $\mathrm{T}$ factor value (4.48 t/ha or $2 \mathrm{t} / \mathrm{ac}$ ) than Miami clay loam. Consequently, all bioenergy scenarios, except for Miscanthus, produced erosion losses that were greater than the soil loss tolerance value for Cincinnati clay loam. Regardless of the bioenergy production on marginally wet Clermont silt loam soil, erosion losses were far below the soil loss tolerance value of $8.96 \mathrm{t} / \mathrm{ha}$, even though it has an erodibility factor $\left(\mathrm{K}_{\mathrm{w}}=0.55\right)$, that is greater than that of all studied soils. This is likely due to the gentle slope $(0 \%$ to $1 \%)$ of Clermont silt loam soils compared to the other soils.

\subsection{Total Phosphorus Losses in Runoff}

Total P losses from switchgrass and Miscanthus production ranged from 2.3 to $7.6 \mathrm{~kg} / \mathrm{ha}$, and 1.5 to $3.5 \mathrm{~kg} / \mathrm{ha}$, respectively (Figure 7). No-till corn and corn grain plus stover removal produced high TP losses, ranging from 4.2 to $9.8 \mathrm{~kg} / \mathrm{ha}$, and 7.0 to $18.7 \mathrm{~kg} / \mathrm{ha}$, respectively (Figure 7). Differences in application rates, application methods (e.g. surface application with no-till practices), and soil erosion associated with management practices on the studied soils were reflected in TP losses for conventional tillage corn with stover removal, switchgrass and Miscanthus (Figure 7). Except on the relatively flat Clermont silt loam, TP losses were dominated by P trans- 


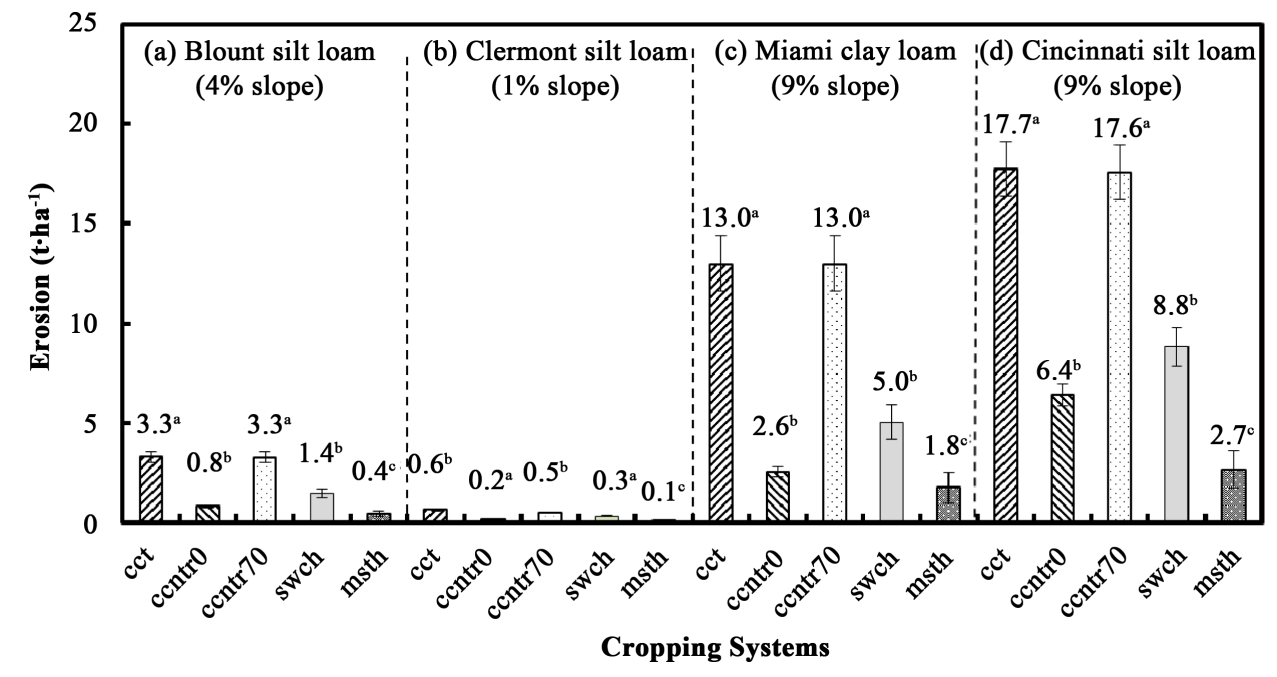

Figure 6. Estimates in mean erosion losses for continuous corn, switchgrass (swch), and Miscanthus $\times$ giganteus ( $m s t h$ ) obtained from long-term GLEAMS-NAPRA model simulations on one prime agricultural soil (a) (Blount silt loam) and three marginal soils; (b) Clermont silt loam; (c) Miami clay loam; $(d)$ (Cincinnati silt loam) in southeastern Indiana. Within each soil, means with the same letter are not significantly different (Tukey test, $\mathrm{p}>0.05$ ).

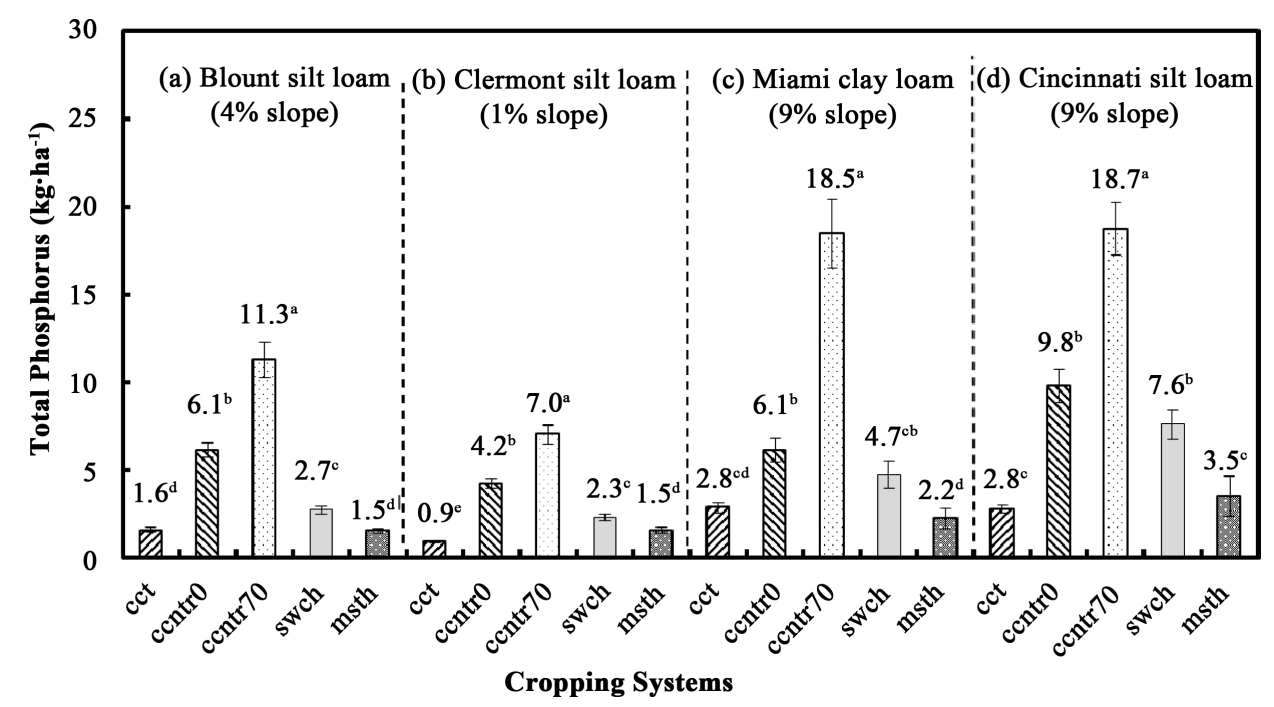

Figure 7. Estimates in mean total phosphorus losses for continuous corn, switchgrass (swch) and Miscanthus ( $m s t h$ ), obtained from long-term GLEAMS-NAPRA model simulations on one prime agricultural soil (a) (Blount silt loam) and three marginal soils; (b) Clermont; (c) Miami clay; (d) (Cincinnati silt) in southeastern Indiana. Within each soil, means with the same letter are not significantly different (Tukey test, $\mathrm{p}>0.05$ ).

ported with sediments (erosion).

Overall, there were higher TP losses from no-till corn practices compared to the production of switchgrass and Miscanthus, which generated higher TP losses than conventional tillage corn across all the studied soils (Figure 7). This pattern could be explained by the method used to apply $\mathrm{P}_{2} \mathrm{O}_{5}$ with no-till. The general practice with corn under fall chisel/spring disk is to incorporate $\mathrm{P}$ fertilizer, which means that lower $\mathrm{P}$ would be available for transport with sediments, which is the dominant form in which P losses from agricultural lands occur. However, P losses should, in principle, be higher for conventional tillage than for no-till corn and switchgrass. Model results also showed that $\mathrm{P}$ losses represent $25 \%-30 \%$ of the $\mathrm{P}$ fertilizer applied each year (Figure 7), suggesting that there is no buildup of $\mathrm{P}$ applied to the surface over time. Another plausible explanation is that the model 
indicates soil P build up near the surface over time, instead of leaching it to subsurface layers. Thus, these results should not be considered conclusive without further assessment of the dynamics of soil $\mathrm{P}$ and perennial grass production. Currently, there are no known long-term monitoring studies that evaluate P annual loads for no-till corn systems.

\subsection{Nitrate Losses in Runoff}

The application of commercial fertilizer with perennial grass production could result in edge-of-field losses (Figure 8). On the studied marginal soils, $\mathrm{NO}_{3}-\mathrm{N}$ losses with surface runoff range from 3.7 to $6.2 \mathrm{~kg} / \mathrm{ha}$ for switchgrass, and 3.8 to $6.6 \mathrm{~kg} / \mathrm{ha}$ for Miscanthus (Figure 8). Statistical analysis indicated that $\mathrm{NO}_{3}-\mathrm{N}$ losses from switchgrass and Miscanthus were not significantly different $(\mathrm{p}>0.05)$ from each other. Owing to higher fertilizer application rates, no-till and conventional tillage corn (except no-till corn plus stover removal) produced high $\mathrm{NO}_{3}-\mathrm{N}$ losses to the edge-of-field (Figure 8). Clermont silt loam, considered marginal due to wetness, produced the highest $\mathrm{NO}_{3}-\mathrm{N}$ losses with estimates of $10.1,7.9$ and $6.0 \mathrm{~kg} /$ ha for tillage corn, no-till corn, and no-till corn with stover removal, respectively. When compared with conventional tillage corn, corn under no-till practice (with or without stover removal) generated lower annual $\mathrm{NO}_{3}-\mathrm{N}$ with runoff because of lower mineralization and accumulation of nutrients in crop residues. Tillage operations (fall chisel/spring disk) with corn production influence the decomposition and release of nitrogen in crop residues. The timing of tillage occurs within high rainfall periods that could make released $\mathrm{NO}_{3}-\mathrm{N}$ available for runoff transport as reported by Thomas et al. [23] who provided detailed discussions on effects of corn stover removal on nitrate losses with surface runoff.

\subsection{Nitrates Leached}

The simulated scenarios suggested that Miscanthus would produce significantly lower $\mathrm{NO}_{3}-\mathrm{N}$ (approximately $90 \%$ lower; $\mathrm{p}<0.05$ ) leached than switchgrass and corn-based production systems (Figure 9), primarily due to differences in fertilizer application rates. Among the three studied soils, Clermont silt loam produced high losses in annual $\mathrm{NO}_{3}-\mathrm{N}$ leached, with highest estimates associated with conventional corn grain $(31.8 \mathrm{~kg} / \mathrm{ha})$ followed by no-till corn plus stover removal (19.5 kg/ha) (Figure 9), and no-till corn (without stover removal) with a range of 6.0 to $16.4 \mathrm{~kg} / \mathrm{ha}$ (Figure 9). In Indiana, Kladivko et al. [64] conducted a 15-year study on a Clermont silt loam for conventional corn and soybean-corn rotation production. The authors observed average annual $\mathrm{NO}_{3}-\mathrm{N}$ losses of 23, 30 and $41 \mathrm{~kg} / \mathrm{ha}$, for 3 different subsurface drain spacings. Although the effects of tillage and no-till

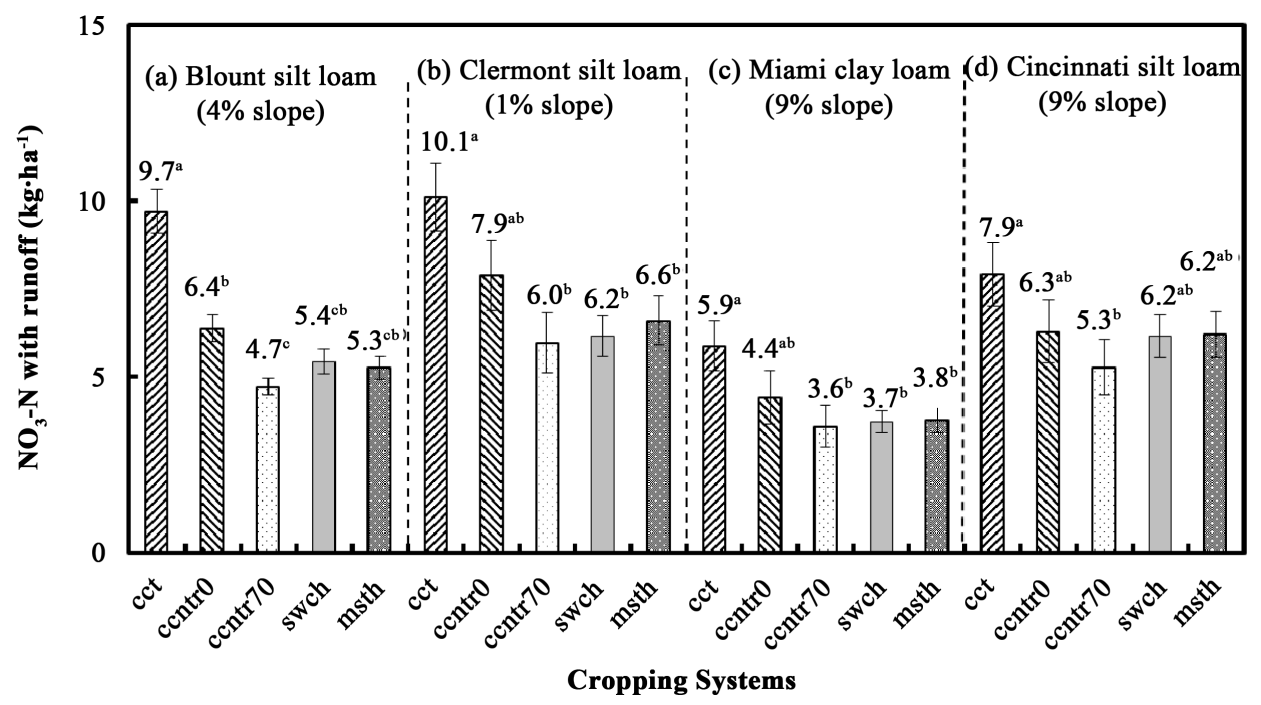

Figure 8. Estimates in mean nitrate losses with runoff for continuous corn, switchgrass (swch) and Miscanthus (msth), obtained from long-term GLEAMS-NAPRA model simulations on one prime agricultural soil (a) (Blount silt loam) and three marginal soils; (b) Clermont; (c) Miami clay; (d) (Cincinnati silt) in southeastern Indiana. Within each soil, means with the same letter are not significantly different (Tukey test, $\mathrm{p}>0.05$ ). 


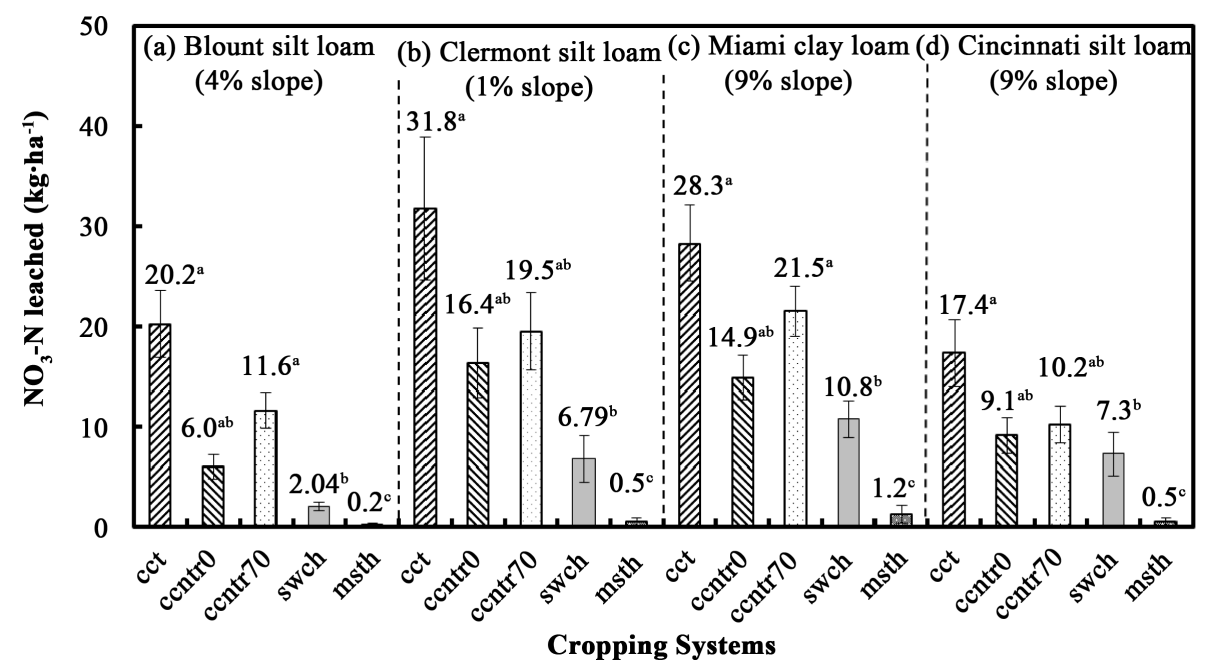

Figure 9. Estimates in mean nitrate leached for continuous corn, switchgrass (swch) and Miscanthus (msth), obtained from long-term GLEAMS-NAPRA model simulations on one prime agricultural soil (a) (Blount silt loam) and three marginal soils; (b) Clermont silt loam; (c) Miami clay loam; (d) (Cincinnati silt loam) in southeastern Indiana. Within each soil, means with the same letter are not significantly different (Tukey test, $\mathrm{p}>0.05$ ).

options (included in the management for the study period), were not separately reported in this study, it appeared that a combined average of the 3 drain spacings (5-, 10- and 20-m) would suggest a $\mathrm{NO}_{3}-\mathrm{N}$ loss of $31.3 \mathrm{~kg} / \mathrm{ha}$ for the 15-year period, which is within ranges of the model estimates (31.8 kg/ha) on Clermont silt loam (Figure 9).

While the simulated percolation results showed that Miscanthus and switchgrass had higher percolation estimates than corn production systems (Figure 5), $\mathrm{NO}_{3}-\mathrm{N}$ leached from grass-based cropping systems was lower than the corn-based production systems. This result could be explained by the differences in the amount of fertilizer applied across the various production systems.

\subsection{Reliability of Simulation Results}

The results from this study showed that simulated runoff, movement of water below the root zone, erosion rates, and nutrient losses were lower for perennial grasses compared to corn systems for bioenergy production. While the relative comparisons can be accepted with confidence, the absolute values predicted by the model should be treated with caution because there were no observed hydrologic and water quality data to enable model calibration for switchgrass and Miscanthus for the study sites. The GLEAMS model has been calibrated at the watershed level and may not completely represent in detail all processes that drive the differences among scenarios at the plot scale. The perennial grasses examined in this study were modeled as established stands over the 32-year period (i.e. without taking into consideration detailed soil water dynamics of the stands over a long period of time). Generally, standing perennial grass stubble would slow down soil erosion in the winter relative to a harvested corn field, especially with a conventional till corn field. The soil tilth of perennial grasses could support greater infiltration compared to a cropped site, and grasses such as Miscanthus and switchgrass extract more soil water over the years than corn because of greater LAI and a longer growing season. The longer growing season will enable these grasses to intercept and hold more rainfall than corn (if corn is harvested and shredded after 110 to 140 days after planting), allowing less water to reach the soil surface. These processes and their effects on soil water were not explicitly represented in the GLEAMS model during scenario simulations to account for greater infiltration and greater soil water extraction. Additional studies (with perhaps detailed process modeling) are therefore needed to better understand the water-use efficiency of large-scale perennial grass production in rain-fed regions.

\section{Conclusions}

Switchgrass and Miscanthus have been identified as putative perennial grasses adaptable to the Midwest United 
States for bioenergy production. The model simulation scenarios completed in this study indicated that growing switchgrass and Miscanthus on marginal quality soils did not considerably affect surface runoff, but decreased annual percolation by 10 to $40 \mathrm{~mm}$ (i.e. by approximately 17\%) when compared with corn-based bioenergy production. Results also suggested a potential for reduction in erosion for Miscanthus across the soil types examined when compared to corn-based bioenergy production. The production of switchgrass and Miscanthus did not significantly impact TP losses in runoff across the soils examined. $\mathrm{NO}_{3}-\mathrm{N}$ losses decreased for switchgrass and Miscanthus relative to conventional tillage and no-till corn. Nitrate leached from fertilized Miscanthus was approximately $90 \%$ lower than $\mathrm{NO}_{3}-\mathrm{N}$ leached from the production of fertilized switchgrass and corn systems.

Miscanthus and switchgrass production on marginal lands would differ across eco-regions in the United States. In this study, optimum switchgrass and Miscanthus yields were assumed to be 10.4 metric ton/ha and 29.6 metric ton/ha, respectively, regardless of soil type, which may not reflect actual yield potentials on marginal soils. In fact, Miscanthus and switchgrass yields on marginal lands would likely be lower than the simulated rates, which could potentially change the hydrology, nutrient dynamics, and analysis with traditionally grown corn. In GLEAMS, crop yields would influence soil loss nutrient dynamics and to a lesser extent hydrology. Given new field data to further calibrate the model, additional studies should be implemented to better understand the hydrology, erosion and nutrient responses of Miscanthus and switchgrass production for meeting bioenergy demands, and to facilitate additional analyses with traditionally grown corn.

\section{Acknowledgements}

Funding for this project was provided by USDA-NIFA (Project Number 2009-51130-06029). Thanks to Frank M. Davis, an information technology specialist, at the USDA-ARS Southeast Watershed Research Laboratory in Tifton, Georgia, for support with the GLEAMS model. Thanks also to Larry Theller in Agricultural and Biological Engineering Department at Purdue University for his help in recreating some figures in black and white.

\section{References}

[1] United States Congress (2007) Senate. Energy Independence and Security Act of 2007. HR 6. 110th Congress, 1st Session.

[2] United States Congress (2008) House of Representatives. The Food Conservation, and Energy Act of 2008. H.R. 2419, 110th Congress, 1st Session, Washington DC, 21 May 2008. http://agriculture.house.gov/inside/FarmBill.html

[3] USDA-FSA (United States Department of Agriculture-Farm Service Agency) (2010) Biomass Crop Assistance Program (BCAP). Fact Sheet: News Release No. 0547.10. United States Department of Agriculture, Farm Service Agency, Washington DC. http://www.fsa.usda.gov/Internet/FSA File/bcapoctrules.pdf

[4] USCRS (United States Congress Research Service) (2012) Biofuels Incentives: A Summary of Federal Programs. CRS Report for Congress. R40110. http://www.fas.org/sgp/crs/misc/R40110.pdf

[5] Dale, V.H., Kline K.L., Wiens J. and Fargione J. (2010) Biofuels: Implications for Land Use and Biodiversity. Biofuels and Sustainability Reports. The Ecological Society of America, Washington DC.

[6] Heaton, E.A., Dohleman, F.G, Miguez, A.F., Juvik, J.A., Lozovaya, V., Widholm. J., Zabotina, O.A., McIsaac, G.F., David, M.B., Voigt, T.B., Boersma, N.N. and Long, S.P. (2010) Miscanthus: A Promising Biomass Crop. In: Kader J.-C. and Delseny, M.Z., Eds., Advances in Botanical Research, Academic Press, Elsevier, 75-137.

[7] Gasparatos, A., Stromberg, P. and Takeuchi, K. (2011) Biofuels, Ecosystem Services and Human Wellbeing: Putting Biofuels in the Ecosystem Services Narrative. Agriculture, Ecosystems \& Environment, 142, 111-128. http://dx.doi.org/10.1016/j.agee.2011.04.020

[8] Cai, X., Zhang, X. and Wang, D. (2011) Land Availability for Biofuel Production. Environmental Science \& Technology, 45, 334-339. http://dx.doi.org/10.1021/es103338e

[9] Heaton, E.A., Dohleman, F.G. and Long, S.P. (2008) Meeting US Biofuel Goals with Less Land: The Potential of Miscanthus. Global Change Biology, 14, 2000-2014. http://dx.doi.org/10.1111/j.1365-2486.2008.01662.X

[10] Stewart, J., Toma, Y.O., Fernandez, F.G., Nishiwaki, A.Y.A., Yamada, T. and Bollero, G. (2009) The Ecology and Agronomy of Miscanthus sinensis, a Species Important to Bioenergy Crop Development, in Its Native Range in Japan: A Review. GCB Bioenergy, 1, 126-153. http://dx.doi.org/10.1111/j.1757-1707.2009.01010.x

[11] Qin, Z., Zhuang, Q., Zhu, X., Cai, X. and Zhang, X. (2011) Carbon Consequences and Agricultural Implications of Growing Biofuel Crops on Marginal Agricultural Lands in China. Environmental Science \& Technology, 45, 1076510772. http://dx.doi.org/10.1021/es2024934

[12] Fargione, J., Plevin, R.J. and Hill, J.D. (2010) The Ecological Impact of Biofuels. Annual Review of Ecology, Evolution, 
and Systematics, 41, 351-377. http://dx.doi.org/10.1146/annurev-ecolsys-102209-144720

[13] Van Loocke, A., Twine, T.E., Zeri, M. and Bernacchi, C.J. (2012) A Regional Comparison of Water Use Efficiency for Miscanthus, Switchgrass and Maize. Agricultural and Forest Meteorology, 164, 82-95. http://dx.doi.org/10.1016/j.agrformet.2012.05.016

[14] Qin, Z., Zhuang, Q. and Chen, M. (2011) Impacts of Land Use Change Due to Biofuel Crops on Carbon Balance, Bioenergy Production, and Agricultural Yield, in the Conterminous United States. GCB Bioenergy, 4, 277-288. http://dx.doi.org/10.1111/j.1757-1707.2011.01129.x

[15] USDOE (United States Department of Energy) (2011) US Billion-Ton Update: Biomass Supply for a Bioenergy and Bioproducts Industry. ORNL/TM-2011/224, Oak Ridge National Laboratory, Oak Ridge, 227 p.

[16] Schmer, M., Vogel, K.P., Mitchell, R.B., Moser, L.E., Eskridge, K.M. and Perrin, R.K. (2006) Establishment Stand Thresholds for Switchgrass Grown as a Bioenergy Crop. Crop Science, 46, 157-161. http://dx.doi.org/10.2135/cropsci2005.0264

[17] Mitchell, R., Vogel, K.P. and Sarath, G. (2008) Managing and Enhancing Switchgrass as a Bioenergy Feedstock. Biofuels, Bioproducts and Biorefining, 2, 530-539. http://dx.doi.org/10.1002/bbb.106

[18] Vogel, K.P. and Mitchell, R.B. (2008) Heterosis in Switchgrass: Biomass Yield in Swards. Crop Science, 48, 21592164. http://dx.doi.org/10.2135/cropsci2008.02.0117

[19] Anderson, E., Arundale, R., Maughan, M., Oladeinde, A., Wycislo, A. and Voigt, T. (2011) Growth and Agronomy of Miscanthus x Giganteus for Biomass Production. Biofuels, 2, 167-183.

[20] De Oliveira, M.E.D., Vaughan, B.E. and Rykiel Jr., E.J. (2005) Ethanol as Fuels: Energy, Carbon Dioxide Balances, and Ecological Footprint. Bioscience, 55, 593-602. http://dx.doi.org/10.1641/0006-3568(2005)055[0593:EAFECD]2.0.CO;2

[21] Thomas, M.A., Engel, B.A. and Chaubey, I. (2009) Water Quality Impacts of Corn Production to Meet Biofuel Demands. ASCE Journal of Environmental Engineering, 135, 1123-1135. http://dx.doi.org/10.1061/(ASCE)EE.1943-7870.0000095

[22] Schilling, K.E., Jha, M.K., Zhang, Y.K., Gassman, P.W. and Wolter, C.F. (2008) Impact of Land Use and Land Cover Change on the Water Balance of a Large Agricultural Watershed: Historical Effects and Future Directions. Water Resources Research, 44, Published Online. http://dx.doi.org/10.1029/2007WR006644

[23] Thomas, M.A., Engel, B.A. and Chaubey, I. (2011) Multiple Corn Stover Removal Rates for Cellulosic Biofuels and Long-Term Water Quality Impacts. Journal of Soil Water Conservation, 66, 431-444. http://dx.doi.org/10.2489/jswc.66.6.431

[24] Cibin, R., Chaubey, I. and Engel, B. (2012) Simulated Watershed Scale Impacts of Corn Stover Removal for Biofuel on Hydrology and Water Quality. Hydrological Processes, 26, 1629-1641. http://dx.doi.org/10.1002/hyp.8280

[25] Kim, S. and Dale, B.E. (2004) Global Potential Bioethanol Production from Wasted Crops and Crop Residues. Biomass \& Bioenergy, 26, 361-375. http://dx.doi.org/10.1016/j.biombioe.2003.08.002

[26] Blanco-Canqui, H., Lal, R., Post, W.M. and Owens, L.B. (2006) Changes in Long-Term No-Till Corn Growth and Yield under Different Rates of Stover Mulch. Agronomy Journal, 98, 1128-1136. http://dx.doi.org/10.2134/agronj2006.0005

[27] Graham, R.L., Nelson, R., Sheehan, J., Perlack, R.D. and Wright, L.L. (2007) Current and Potential US Corn Stover Supplies. Agronomy Journal, 99, 1-11. http://dx.doi.org/10.2134/agronj2005.0222

[28] Nelson, R.G., Ascough, J.C. and Langemeier, M.R. (2006) Environmental and Economic Analysis of Switchgrass Production for Water Quality Improvement in Northeast Kansas. Journal of Environmental Management, 79, 336-347.

[29] Ng, T.L., Eheart, J.W., Cai, X.M. and Miguez, F. (2010) Modeling Miscanthus in the Soil and Water Assessment Tool (SWAT) to Simulate Its Water Quality Effects as a Bioenergy Crop. Environmental Science \& Technology, 44, 71387144. http://dx.doi.org/10.1021/es9039677

[30] Parajuli, P.B., and Duffy, S.E. (2013) Quantifying Hydrologic and Water Quality Responses to Bioenergy Crops in Town Creek Watershed in Mississippi. Journal of Sustainable Bioenergy Systems, 3, 202-208. http://dx.doi.org/10.4236/jsbs.2013.33028

[31] Thomas, M.A. (2011) Environmental Implications of Feedstock Production Practices for Bioenergy. Ph.D. Dissertation, Purdue University, West Lafayette.

[32] Brechbill, S.C., Tyner, W.E. and Ileleji, K.E. (2011) The Economics of Biomass Collection and Transportation and Its Supply to Indiana Cellulosic and Electric Utility Facilities. BioEnergy Research, 4, 141-152. http://dx.doi.org/10.1007/s12155-010-9108-0

[33] Soil Survey Staff (2011) Natural Resources Conservation Service, United States Department of Agriculture. Soil Survey Geographic (SSURGO) Database for Decatur County, Indiana. http://soildatamart.nrcs.usda.gov 
[34] USDA-NASS (United States Department of Agriculture-National Agricultural Statistics Service) (2010) CropScape: Crop Land Data Layer. US Department of Agriculture, National Agricultural Statistics Service: Research and Development Division. http://nassgeodata.gmu.edu/CropScape/

[35] Leonard, R.A., Knisel, W.G. and Still, D.A. (1987) GLEAMS: Groundwater Loading Effects of Agricultural Management Systems. Transactions of ASAE, 30, 1403-1418. http://dx.doi.org/10.13031/2013.30578

[36] USDA-ARS (United States Department of Agriculture-Agricultural Research Service) (2003) User’s Guide. Revised Universal Soil Loss Equation Version 2. USDA-ARS, Washington DC. http://fargo.nserl.purdue.edu/rusle2 dataweb/userguide/RUSLE2-2-3-03.pdf

[37] Knisel, W.G. and Davis, F.M. (2000) Groundwater Loading Effects of Agricultural Management Systems. Version 3.0. User Manual. US Department of Agriculture (USDA), Agricultural Research Service (ARS), Southeast Watershed Research Laboratory, Tifton, Georgia SEWRL-WGK/FMD-050199.

[38] Nicks, A.D., Lane, L.J. and Gander, G.A. (1995) Weather Generator. Chapter 2 in USDA-Water Erosion Prediction Project: Hillslope Profile and Watershed Model Documentation. Flanagan, D.C. and Nearing, M.A., Eds., NSERL Report No. 10, USDA-ARS National Erosion Research Laboratory, West Lafayette.

[39] Baffaut, C., Nearing, M.A. and Nicks, A.D. (1996) Impact of Cligen Parameters on WEPP-Predicted Average Annual Soil Loss. Transactions of ASAE, 39, 447-457. http://dx.doi.org/10.13031/2013.27522

[40] Williams, J.R. (1990) The Erosion-Productivity Impact Calculator (EPIC) Model: A Case History. Philosophical Transactions of the Royal Society: Biological Sciences, 329, 421-428. http://dx.doi.org/10.1098/rstb.1990.0184

[41] Arnold, J.G., Srinivasan, R., Muttiah, R.S. and Williams J.R. (1998) Large Area Hydrologic Modeling and Assessment Part 1: Model Development. JAWRA Journal of the American Water Resources Association, 34, 73-89. http://dx.doi.org/10.1111/j.1752-1688.1998.tb05961.x

[42] Adeuya, R.K., Lim, K.J., Engel, B.A. and Thomas, M.A. (2005) Modeling the Average Annual Nutrient Losses of Two Watersheds in Indiana Using GLEAMS-NAPRA. Transactions of ASABE, 48, 1739-1749.

[43] Thomas, M.A., Engel, B.A., Arabi, M., Zhai, T., Farnsworth, R. and Frankenberger, J.R. (2007) Evaluation of Nutrient Management Plans Using an Integrated Modeling Approach. Applied Engineering in Agriculture, 23, 747-755. http://dx.doi.org/10.13031/2013.24058

[44] Jetten, V., de Roo, A. and Favis-Mortlock, D. (1999) Evaluation of Field-Scale and Catchment-Scale Soil Erosion Mo dels. Catena, 37, 521-541. http://dx.doi.org/10.1016/S0341-8162(99)00037-5

[45] Knisel, W.G., Leonard, R.A., Davis, F.M. and Sheridan, J.M. (1991) Water Balance Components in the Georgia Coastal Plain: A GLEAMS Model Validation and Simulation. Journal of Soil Water Conservation, 46, 450-456.

[46] Sichani, S.A., Engel, B.A., Monke, E.J., Eigel, J.D. and Kladivko, E.J. (1991) Validating GLEAMS with Pesticide Field Data on a Clermont Silt Loam Soil. Transactions of ASAE, 34, 1732-1737. http://dx.doi.org/10.13031/2013.31794

[47] Lim, K.J., Engel, B.A. and Tang, Z. (2006) Identifying Regional Groundwater Risk Areas Using a WWW GIS Model System. International Journal of Risk Assessment and Management, 6, 316-329. http://dx.doi.org/10.1504/IJRAM.2006.009549

[48] Barnes, R.F., Nelson, C.J., Collins, M. and Moore, K.J. (2003) Forages: An Introduction to Grassland Agriculture. 6th Edition, Vol. I, Iowa State Press, Blackwell Publishing Company, Ames.

[49] Engel, B., Chaubey, I., Thomas, M., Saraswat, D., Murphy, P. and Bhaduri, B. (2010) Biofuels and Water Quality: Challenges and Opportunities for Simulation Modeling. Future Science Group: Biofuels, 1, 463-477.

[50] Hanson, J.D. and Johnson, H.A. (2005) Germination of Switchgrass under Various Temperature and pH Regimes. Seed Technology, 27, 203-210.

[51] Parrish, D.J. and Fike, J.H. (2005) The Biology and Agronomy of Switchgrass for Biofuels. Critical Reviews in Plant Sciences, 24, 423-459. http://dx.doi.org/10.1080/07352680500316433

[52] Fike, J.H., Parrish, D.J., Wolfe, D.D., Balasko, J.A., Green Jr., J.T., Rasnake, M. and Reynolds, J.H. (2006) LongTerm Yield Potential of Switchgrass-For Biofuel Systems. Biomass and Bioenergy, 30, 198-206. http://dx.doi.org/10.1016/j.biombioe.2005.10.006

[53] Vogel, K.P., Brejda, J.J., Walters, D.T. and Buxton, D.R. (2002) Switchgrass Biomass Production in the Midwest USA: Harvest and Nitrogen Management. Agronomy Journal, 94, 413-420. http://dx.doi.org/10.2134/agronj2002.0413

[54] USDA-NRCS (United States Department of Agriculture-Natural Resources Concervation Service) (2008) Cave-inRock Switchgrass (Panicum virgatum L.): An Improved Conservation Plant Developed by Elsberry Plant Materials Center. Elsberry Plant Materials Center, United States Department of Agriculture, Natural Resources Conservation Service, Elsberry.

[55] Montgomery, D.C. (2004) Design and Analysis of Experiment. 6th Edition, John Wiley and Sons, New York. 
[56] Statistical Analysis Software (SAS) (2004) Version 9.2. SAS Institute Inc., Cary.

[57] Nyakatawa, E.Z., Mays, D.A., Tolbert, V.R., Green, T.H. and Bingham, L. (2006) Runoff, Sediment, Nitrogen, and Phosphorus Losses from Agricultural Land Converted to Sweetgum and Switchgrass Bioenergy Feedstock Production in North Alabama. Biomass and Bioenergy, 30, 655-664.

[58] McIsaac, G.F., David, M.B. and Mitchell, C.A. (2010) Miscanthus and Switchgrass Production in Central Illinois: Impacts on Hydrology and Inorganic Nitrogen Leaching. Journal of Environmental Quality, 39, 1790-1799. http://dx.doi.org/10.2134/jeq2009.0497

[59] Le, P.V.V., Kumar, P. and Drewry, D.T. (2011) Implications for the Hydrologic Cycle under Climate Change Due to the Expansion of Bioenergy Crops in the Midwestern United States. Proceedings of the National Academy of Sciences of the United States of America, 108, 15085-15090. http://dx.doi.org/10.1073/pnas.1107177108

[60] Wilson, H.M., Cruse, R.M. and Burras, C.L. (2011) Perennial Grass Management Impacts on Runoff and Sediment Export from Vegetated Channels in Pulse Flow Runoff Events. Biomass and Bioenergy, 35, 429-436. http://dx.doi.org/10.1016/j.biombioe.2010.08.059

[61] Horner, G.M. (1960) Effect of Cropping Systems on Runoff, Erosion, and Wheat Yields. Agronomy Journal, 52, 342344. http://dx.doi.org/10.2134/agronj1960.00021962005200060012x

[62] Martin, P., Joannon, A. and Piskiewicz, N. (2010) Temporal Variability of Surface Runoff Due to Cropping Systems in Cultivated Catchment Areas: Use of the DIAR Model for the Assessment of Environmental Public Policies in the Pays de Caux (France). Journal of Environmental Management, 91, 869-878. http://dx.doi.org/10.1016/j.jenvman.2009.11.003

[63] Finch, J.W. and Riche, A.B. (2010) Interception Losses from Miscanthus at a Site in South-East England-An Application of the Gash Model. Hydrological Processes, 24, 2594-2600. http://dx.doi.org/10.1002/hyp.7673

[64] Kladivko, E.J., Frankenberger, J.R., Jaynes, D.B., Meek, D.W., Jenkinson, B.J. and Fausey, N.R. (2004) Nitrate Leaching to Subsurface Drains as Affected by Drain Spacing and Changes in Crop Production System. Journal of Environmental Quality, 33, 1803-1813. http://dx.doi.org/10.2134/jeq2004.1803 
Scientific Research Publishing (SCIRP) is one of the largest Open Access journal publishers. It is currently publishing more than 200 open access, online, peer-reviewed journals covering a wide range of academic disciplines. SCIRP serves the worldwide academic communities and contributes to the progress and application of science with its publication.

Other selected journals from SCIRP are listed as below. Submit your manuscript to us via either submit@scirp.org or Online Submission Portal.
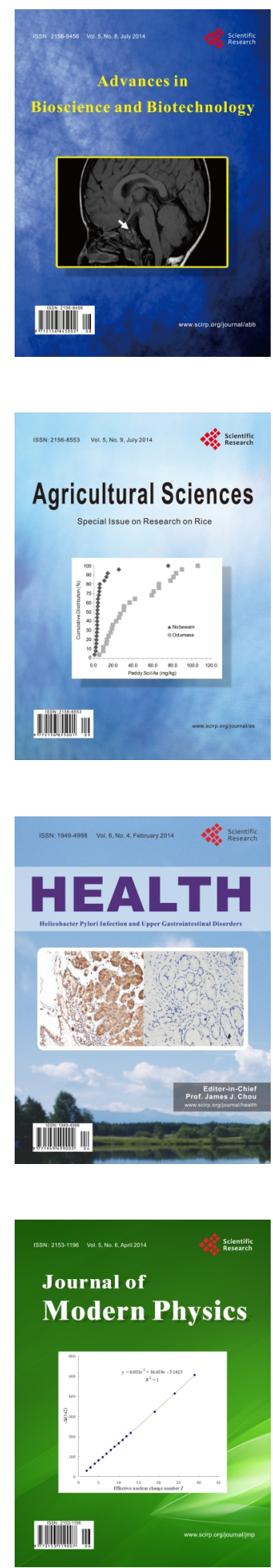
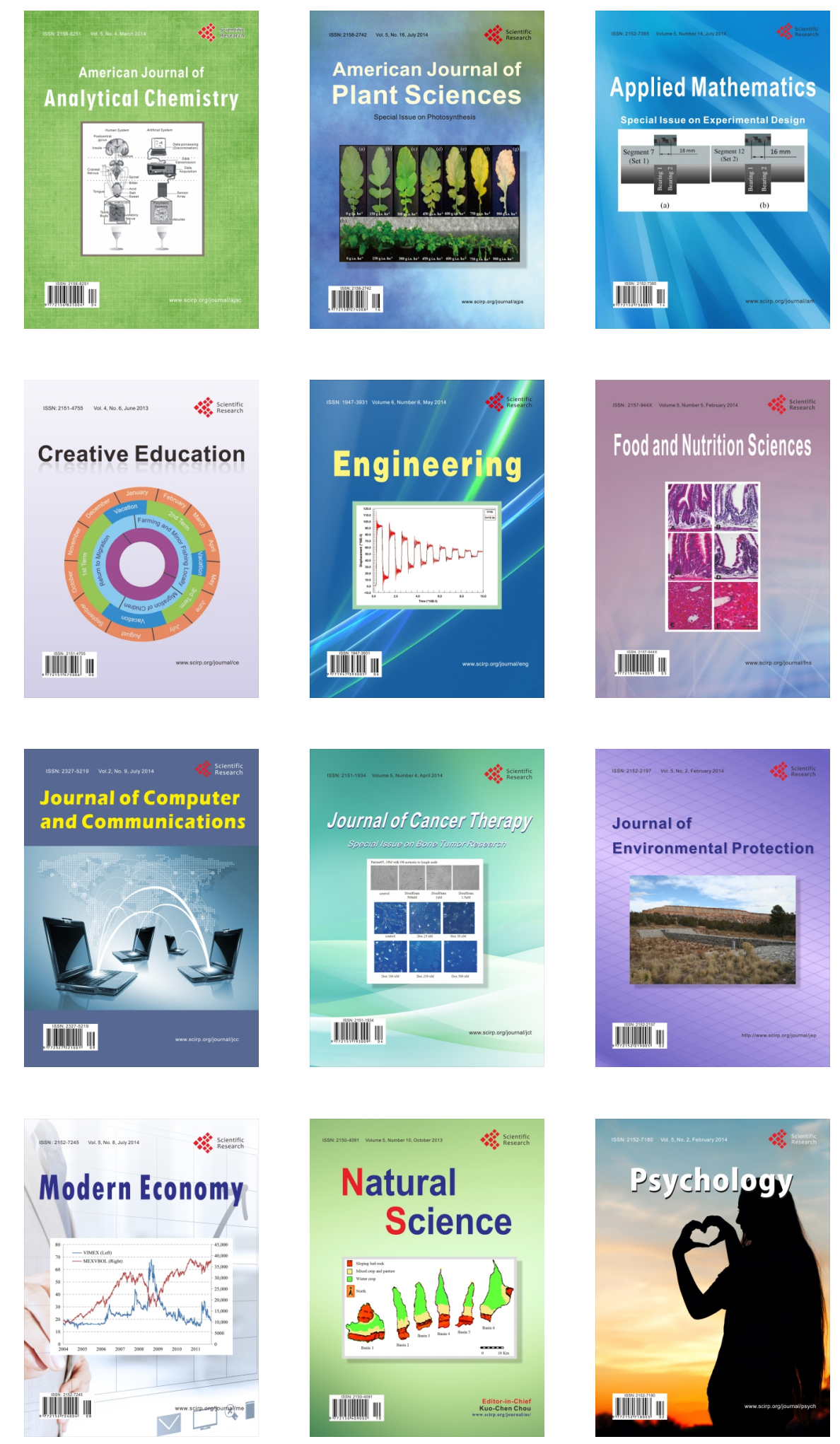